\title{
Measurement of iron stores in cirrhosis using diethylenetriamine penta-acetic acid
}

\author{
MICHAEL BARRY, GUISEPPE CARTEI, AND SHEILA SHERLOCK \\ From The Department of Medicine, The Royal Free Hospital, London
}

SUMMARY The chelating agent diethylenetriamine penta-acetic acid was used to measure iron stores in 83 patients with chronic liver disease. Iron chelation was normal in patients with chronic cholestasis. Chelation was increased above the control range in 14 out of 26 patients with alcoholic cirrhosis, in nine out of 28 patients with non-alcoholic cirrhosis, and in 11 out of 15 cirrhotics with a portacaval anastomosis. Iron stores in excess of $1.5 \mathrm{~g}$ were predicted from the results in 24 subjects; however, in only three were the values in the range found in propositi with untreated idiopathic haemochromatosis. Increased chelation did not correlate with hepatocellular impairment per se but was associated in 18 cases with surgical or large spontaneous portal systemic shunts. Exogenous factors for excess iron were present in three cases with alcoholic cirrhosis and portal systemic collaterals in one, but no special factor apart from alcoholism was apparent in the remainder.

The correlation between chelatable iron and stainable liver iron content was not close and was better in haemochromatosis than in other forms of cirrhosis; in some cases considerable siderosis was present with normal or only slightly increased chelation values.

A close association between iron excess and cirrhosis has long been recognized, and cirrhosis is regarded as potentially an iron-loading disorder (Kent and Popper, 1968). Alcoholism, particularly heavy wine consumption (Gilbert and Grenet, 1896; André, 1961; MacDonald, 1964; Perman, 1967), is accepted as an important factor, and portal systemic shunting may also have a pathogenetic role (Tuttle, Figueroa, and Grossman, 1959; Hoffbauer, 1960; Tisdale, 1961 ; Schaefer, Amick, Oikawa, and Schiff, 1962; Grace and Balint, 1966; Nixon, 1966). However, some degree of siderosis is common in liver disease generally (Zimmerman, Chomet, Kulesh, and McWhorter, 1967; Williams, Williams, Scheuer, Pitcher, Loiseau, and Sherlock, 1966) and its significance is often difficult to interpret. Quantitative estimates of storage iron in a large Received for publication 23 June 1970. series of patients with cirrhosis have yet to be reported.

Chelating agents, such as diethylenetriamine penta-acetic acid (DTPA), provide an indirect means of measuring total body storage iron. A close and apparently specific relationship was found between DTPA-chelatable body iron and mobilizable storage iron in patients with iron excess, enabling the size of the stores to be reliably predicted (Barry, Cartei, and Sherlock, 1970). The present paper describes the findings with this technique in patients with chronic liver disease.

\section{Methods}

The methods used for determination of DTPAchelatable iron, serum iron, and total iron-binding 
capacity, and for assessing stainable liver iron, have already been described (Barry et al, 1970).

\section{Patients Studied}

Observations were made in 83 patients with chronic liver disease. The subjects (Table I) were divisible into groups with chronic cholestasis (14 cases), alcoholic cirrhosis (26 cases), nonalcoholic cirrhosis (28 cases), and cirrhosis with end-to-side portacaval anastomosis (15 cases). The control groups and patients with untreated and treated idiopathic haemochromatosis have been described previously (Barry et al, 1970). In addition there were seven patients with iron excess secondary respectively to sideroblastic anaemia (four cases), thalassaemia major, hereditary spherocytosis, and aplastic anaemia with multiple blood transfusions (one case each).

The diagnosis in the patients with chronic cholestasis was gallstones (two cases), primary biliary cirrhosis (three cases), traumatic and malignant biliary stricture (three cases respectively), drug-induced cholestasis (two cases), and Dubin-Johnson jaundice (one case). The mean duration of jaundice was 16 months (range two weeks-six years).

At least 12 of the patients with alcoholic cirrhosis had been drinking heavily up to the time of admission to hospital. Two were heavy wine drinkers, the others consuming mainly beer and spirits. One had received multiple transfusions elsewhere for a haemolytic anaemia. Five cases were referred following variceal haemorrhage having been transfused with 6-22 units of blood (mean 17.2). One had chronic encephalopathy due to large spontaneous collaterals.

A diagnosis of active chronic hepatitis had been made at some time during the clinical course in 11 of the patients with non-alcoholic cirrhosis. Apart from three cases of Wilson's disease the pathogenesis of the cirrhosis in the remainder was unknown. Seven were referred following variceal haemorrhage, six having been transfused with 4-16 units of blood (mean 6.4); one case had received 91 units. Seven patients required treatment for chronic portal systemic encephalopathy.

The portacaval anastomosis group comprised 13 cases of cryptogenic cirrhosis, one case of $\vec{\Rightarrow}$ alcoholic cirrhosis, and one with probable $\stackrel{5}{+}$ primary biliary cirrhosis. The shunt had been present for a mean of 3.8 years (range 0.8-6.9 years). Nine patients required treatment for chronic encephalopathy.

\section{Results}

Details of the groups studied are summarized in Table I and the results are shown in Figure 1.

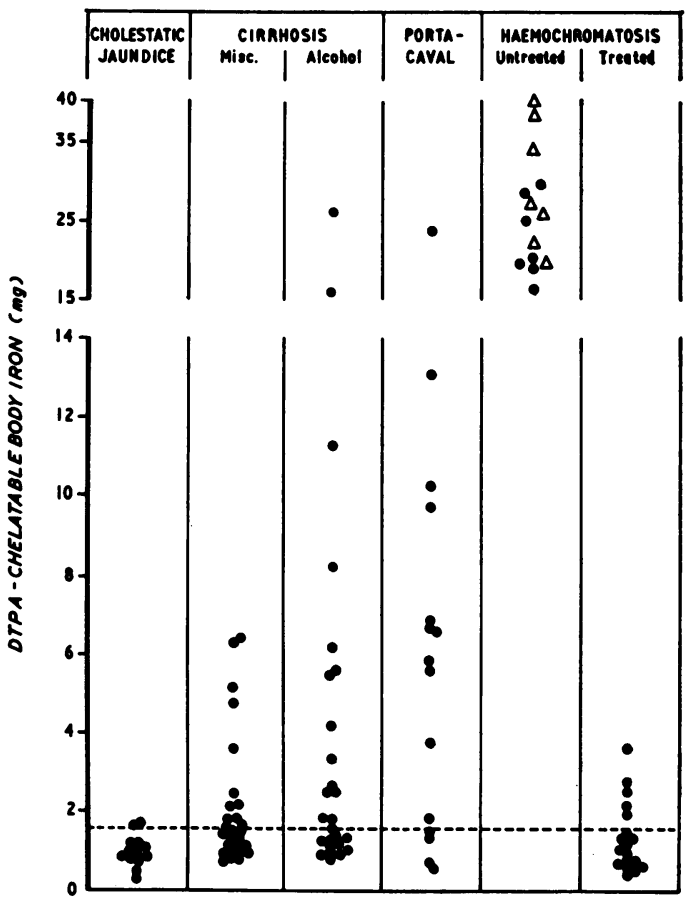

Fig. 1 DTPA-chelatable iron in liver diseases and idiopathic haemochromatosis. $\triangle=$ secondary haemochromatosis. The horizontal broken line indicates the upper limit of the control range.

\begin{tabular}{|c|c|c|c|c|c|c|c|}
\hline Group (no.) & $\begin{array}{l}\mathrm{Hb} \\
(\mathrm{g} / 100 \mathrm{ml})\end{array}$ & $\begin{array}{l}\text { Serum Iron } \\
(\mu \mathrm{g} / 100 \mathrm{ml})\end{array}$ & $\begin{array}{l}\text { Total Iron- } \\
\text { binding Capacity } \\
(\mu \mathrm{g} / 100 \mathrm{ml})\end{array}$ & $\begin{array}{l}\text { Urinary Iron } \\
(\mu g)\end{array}$ & $\begin{array}{l}D T P A \\
\text { chelat } \\
(\mathrm{mg})\end{array}$ & able Iron & $\begin{array}{l}\text { No. with Hepatic } \\
\text { Siderosis/No. } \\
\text { Biopsied }\end{array}$ \\
\hline Control males (16) & $14.9 \pm 0.3$ & $121 \pm 8$ & $345 \pm 14$ & $160 \pm 20$ & 0.87 & \pm 0.90 & - \\
\hline $\begin{array}{l}\text { Control females (9) } \\
\text { Untreated idiopathic }\end{array}$ & $14.3 \pm 0.4$ & $132 \pm 19$ & $395 \pm 17$ & $90 \pm 10$ & $0 \cdot 54$ & \pm 0.70 & 一 \\
\hline $\begin{array}{l}\text { haemochromatosis ( } 7) \\
\text { Treated idiopathic }\end{array}$ & $15.0 \pm 0.6$ & $300 \pm 26$ & $327 \pm 22$ & $9,959 \pm 902$ & 22.46 & \pm 1.93 & $7 / 7$ \\
\hline $\begin{array}{l}\text { haemochromatosis (9) } \\
\text { Secondary }\end{array}$ & $12 \cdot 3 \pm 0.6$ & $66 \pm 12$ & $392 \pm 15$ & $157 \pm 20$ & 0.78 & $\pm 0 \cdot 80$ & $0 / 6$ \\
\hline haemochromatosis (7) & $9 \cdot 8 \pm 1 \cdot 1$ & $271 \pm 27$ & $278 \pm 25$ & $9,066 \pm 984$ & $29 \cdot 38$ & $\pm 3 \cdot 12$ & $4 / 4$ \\
\hline Chronic cholestasis (14) & $12 \cdot 3 \pm 0.4$ & $114 \pm 11$ & $420 \pm 17$ & $166 \pm 16$ & 0.98 & $\pm 0 \cdot 10$ & $0 / 13$ \\
\hline Alcoholic cirrhosis (26) & $13.4 \pm 0.5$ & $140 \pm 14$ & $320 \pm 16$ & $880 \pm 292$ & $4 \cdot 26$ & $\pm 1 \cdot 12$ & $7 / 20$ \\
\hline Non-alcoholic cirrhosis (28) & $12.8 \pm 0.3$ & $114 \pm 12$ & $328 \pm 16$ & $334 \pm 74$ & $1 \cdot 90$ & \pm 0.29 & $7 / 27$ \\
\hline Portacaval shunt (15) & $12 \cdot 8 \pm 0.4$ & $170 \pm 11$ & $260 \pm 15$ & $2,169 \pm 780$ & $6 \cdot 53$ & \pm 1.57 & $4 / 5$ \\
\hline
\end{tabular}

Table I Groups studied ${ }^{1}$

${ }^{1}$ Mean $\pm \mathbf{S E M}$ value given 
CONTROLS

The findings in controls have already been described (Barry et al, 1970). The values for DTPA-chelatable iron ranged from 0.29 to 1.59 mg. The upper limit of normal was taken as $1.60 \mathrm{mg}$.

IDIOPATHIC AND SECONDARY HAEMOCHROMATOSIS

The findings in the patients with secondary haemochromatosis did not differ significantly from those previously described in propositi with idiopathic haemochromatosis (Barry et al, 1970).

\section{CHRONIC CHOLESTASIS}

DTPA-chelatable iron showed no significant deviation from the control range in the 14 patients studied. The mean value was higher than in controls but the difference was not significant. Many of the patients had a mild hypochromic normocytic anaemia, not obviously due to iron deficiency, and it is possible that redistribution of iron from the haemoglobin compartment to the stores may account for the slightly higher chelation values than in the controls. This was supported by the presence of a weak inverse correlation between DTPA-chelatable iron and haemoglobin concentration in the 10 male patients $(\mathrm{r}=-0 \cdot 70, \mathrm{P}<0.05)$.

\section{ALCOHOLIC CIRRHOSIS}

DTPA-chelatable iron was raised in 14 of the 26 subjects, the values in nine indicating an iron load $>1.5 \mathrm{~g}$; two of these were heavy wine drinkers, another had been transfused on many occasions for a haemolytic anaemia, and one had chronic encephalopathy due to large spontaneous collaterals.

\section{NON-ALCOHOLIC CIRRHOSIS}

DTPA-chelatable iron was raised in nine of the 28 patients, but in only four were the values indicative of an iron load $>1.5 \mathrm{~g}$. Six of the patients with raised values had chronic encephalopathy due to large spontaneous collaterals.

\section{FACTORS ASSOCIATED WITH INCREASED CHELATION}

These were examined using the combined results of the alcoholic and non-alcoholic cirrhosis groups.

\section{Siderosis}

Stainable liver iron was demonstrable in 14 out of the 47 cirrhotics biopsied. It was present in only three $(9.4 \%)$ of 28 biopsied cases with normal DTPA-chelatable iron, as compared with 11 $(58 \%)$ of 19 biopsied cases with increased chelation. The correlation between stainable liver iron grade and DTPA-chelatable iron was not close, being better in haemochromatosis (Fig. 2) than in other forms of cirrhosis (Fig. 3).

\section{Poor liver cell function}

The 34 patients without demonstrable hepatic siderosis were divided into two groups, those with normal (25 cases) and those with increased chelatable iron (8 cases) respectively. As shown in Table II these groups did not differ significantly

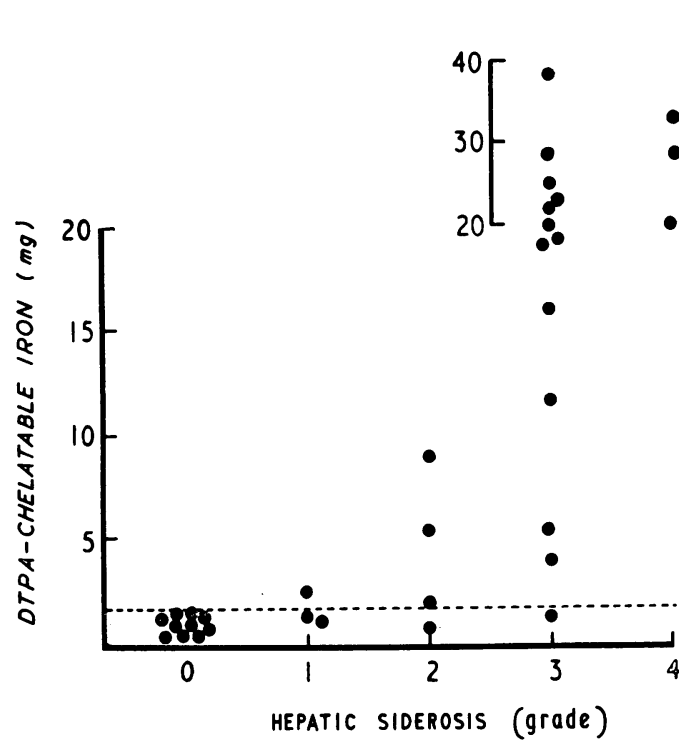

Fig. 2 Relation between DTPA-chelatable iron and stainable liver cell iron in patients with hasmochromatosis.

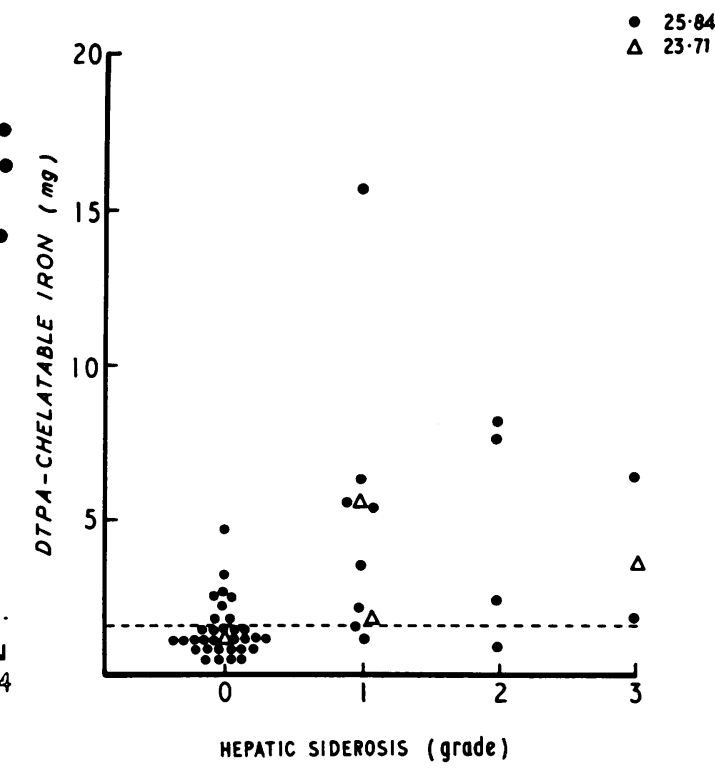

Fig. 3 Relation between DTPA-chelatable iron and stainable liver iron in patients with cirrhosis. $\Delta=$ portacaval anastomosis. 


\begin{tabular}{|c|c|c|c|}
\hline & $\begin{array}{l}\text { Normal } \\
\text { Chelation }\end{array}$ & $\begin{array}{l}\text { Increased } \\
\text { Chelation }\end{array}$ & $t$ Test \\
\hline $\begin{array}{l}\text { No. in group } \\
\text { DTPA-chelatable }\end{array}$ & 26 & 8 & 一 \\
\hline iron $(\mathrm{mg})$ & $1 \cdot 14 \pm 0.06$ & $2.71 \pm 0.35$ & - \\
\hline $\mathrm{Hb}(\mathrm{g} / 100 \mathrm{ml})$ & $13.0 \pm 0.4$ & $12 \cdot 2 \pm 0.7$ & $P>0.3$ \\
\hline $\begin{array}{l}\text { Serum iron }(\mu \mathrm{g} / 100 \mathrm{ml}) \\
\text { Total iron-binding }\end{array}$ & $110 \pm 12$ & $114 \pm 22$ & $P>0.8$ \\
\hline $\begin{array}{l}\text { capacity }(\mu \mathrm{g} / 100 \mathrm{ml}) \\
\text { Serum bilirubin }\end{array}$ & $345 \pm 16$ & $337 \pm 22$ & $P>0.7$ \\
\hline $\begin{array}{l}(\mathrm{mg} / 100 \mathrm{ml}) \\
\text { Asparate transaminase }\end{array}$ & $2 \cdot 0 \pm 0 \cdot 6$ & $3.0 \pm 1.7$ & $P>0.4$ \\
\hline (IU/I) & $42 \pm 12$ & $40 \pm 8$ & $P>0.4$ \\
\hline Serum albumin $(\mathrm{g} / 100 \mathrm{ml})$ & $3.8 \pm 0.2$ & $3.6 \pm 0.4$ & $P>0.4$ \\
\hline
\end{tabular}

Table II Cirrhosis with siderosis: comparison of groups with normal and increased DTPA-chelatable iron ${ }^{1}$

${ }^{1}$ Mean \pm SEM values are given.

with respect to liver function, suggesting that increased iron chelation by DTPA in cirrhosis is not a function of hepatocellular impairment per se, as has been found with desferrioxamine.

\section{Spontaneous portal systemic shunts}

Seven $(30.4 \%)$ of the 23 cirrhotics with increased DTPA-chelatable iron had spontaneous portal systemic collaterals of sufficient size to cause symptomatic encephalopathy. Only one $(3.2 \%)$ of the 31 patients with normal chelatable iron had encephalopathy. Details of the patients with encephalopathy are summarized in Table III.

\section{Serum iron concentration}

The relationship between serum iron and DTPAchelatable iron in haemochromatosis differed from that in other forms of cirrhosis and in neither case could be satisfactorily expressed as a single mathematical function. This will be the subject of a separate paper. Increased chelation was associated with a serum iron level $>205$ $\mu \mathrm{g} / 100 \mathrm{ml}$ (the $95 \%$ upper confidence limit of our normal range) in 34 out of 42 observations in haemochromatosis, and in six out of 25 observations in alcoholic and cryptogenic cirrhosis. A raised serum iron level was associated with normal chelatable iron only once in 42 observations.

\section{PORTACAVAL ANASTOMOSIS}

DTPA-chelatable iron was normal in four and elevated in 11 patients with an end-to-side portacaval anastomosis. The mean value was higher than that in other cirrhotics (Table I) and was associated with a higher mean serum iron level and a greater incidence of siderosis. However, in only one case (the only alcoholic in the group) was iron chelation in the range observed in propositi with idiopathic haemochromatosis.

Chelatable iron in the portacaval patients was significantly greater than in cirrhotics with recent haematemesis awaiting shunt surgery, though not in cirrhotics with chronic encephalopathy due to large spontaneous collaterals (Fig. 4). Details of these groups are summarized in Table III. The portacaval patients differed significantly from the cirrhotics studied before operation with regard to serum iron and total iron-binding capacity and in the incidence of hepatic siderosis, though not in the amount of exogenous iron administered throughout the clinical course. Comparison of the portacaval patients with the cirrhotics with large spontaneous shunts revealed no significant difference in iron status or liver function. However, a similar comparison with all other cryptogenic cirrhotics showed that chelatable iron and serum iron values were significantly higher in the portacaval patients although the two groups were comparable with regard to liver function (Table III). These findings suggest that in cirrhosis portal systemic shunting per se is associated with increased iron chelation, the effect occurring independently of hepatocellular impairment.

In the portacaval patients chelatable iron showed no correlation with time since operation $(\mathrm{r}=-\mathbf{0} \cdot 22)$ or with the total quantity of iron or blood administered throughout the clinical course $(r=-0.07)$.

\section{Discussion}

Iron chelation by desferrioxamine has been found to vary significantly with hepatocellular

\begin{tabular}{|c|c|c|c|c|}
\hline & Surgical Shunts ${ }^{1}$ & $\begin{array}{l}\text { Cirrhosis and Recent } \\
\text { Haematemesis }\end{array}$ & $\begin{array}{l}\text { Cirrhosis with } \\
\text { Encephalopathy }\end{array}$ & $\begin{array}{l}\text { All Other Cryptogenic } \\
\text { Cirrhosis }\end{array}$ \\
\hline No. in group & 15 & 10 & 8 & 16 \\
\hline $\begin{array}{l}\text { DTPA-chelatable iron }(\mathrm{mg}) \\
\text { Serum iron }(\mu \mathrm{g} / 100 \mathrm{ml}) \\
\text { Total iron-binding capacity }(\mu \mathrm{g} / 100 \mathrm{ml}) \\
\mathrm{Hb}(\mathrm{g} / 100 \mathrm{ml}) \\
\text { Iron administered }(\mathrm{g})^{4} \\
\text { No. with siderosis } / \mathrm{no} \text {. biopsied } \\
\text { Serum bilirubin }(\mathrm{mg} / 100 \mathrm{ml}) \\
\text { Asparate transaminase }(\mathrm{IU} / \mathrm{l}) \\
\text { Serum albumin }(\mathrm{g} / 100 \mathrm{ml})\end{array}$ & $\begin{array}{l}6 \cdot 53 \pm 1 \cdot 57 \\
170 \pm 11 \\
260 \pm 15 \\
12 \cdot 8 \pm 0 \cdot 4 \\
2 \cdot 42 \pm 0.41 \\
4 / 5 \\
2 \cdot 7 \pm 0.4 \\
28 \pm 4 \\
3 \cdot 3 \pm 0.1\end{array}$ & $\begin{array}{l}1 \cdot 18 \pm 0 \cdot 15^{2} \\
98 \pm 17^{2} \\
393 \pm 21^{2} \\
12 \cdot 9 \pm 0 \cdot 4 \\
4 \cdot 38 \pm 1 \cdot 87 \\
0 / 10 \\
1 \cdot 3 \pm 0 \cdot 3^{2} \\
19 \pm 3^{2} \\
4 \cdot 2 \pm 0 \cdot 1^{2}\end{array}$ & $\begin{aligned} 3.64 & \pm 0.66 \\
148 & \pm 28 \\
265 & \pm 25 \\
12 \cdot 7 & \pm 0 \cdot 7 \\
- & \\
4 / 6 & \\
2 \cdot 1 & \pm 0.6 \\
27 & \pm 5 \\
3 \cdot 0 & \pm 0.3\end{aligned}$ & $\begin{array}{l}1 \cdot 62 \pm 0 \cdot 34^{8} \\
116 \pm 17^{3} \\
321 \pm 22 \\
13 \cdot 3 \pm 0 \cdot 4 \\
3 / 15 \\
3 \cdot 1 \pm 1 \cdot 1 \\
56 \pm 18 \\
3 \cdot 7 \pm 0 \cdot 3\end{array}$ \\
\hline
\end{tabular}

Table III Comparison of surgical shunt patients with other cirrhosis groups ${ }^{5}$

${ }^{1}$ Test of difference (Wilcoxon) from surgical shunt group not significant unless indicated.

${ }^{2} \mathbf{P}<0.01$.

${ }^{2} \mathrm{P}<0.02$.

${ }^{4} \mathrm{By}$ IM injection or as transfused haemoglobin-iron.

${ }^{5}$ Mean \pm SEMI values are given. 


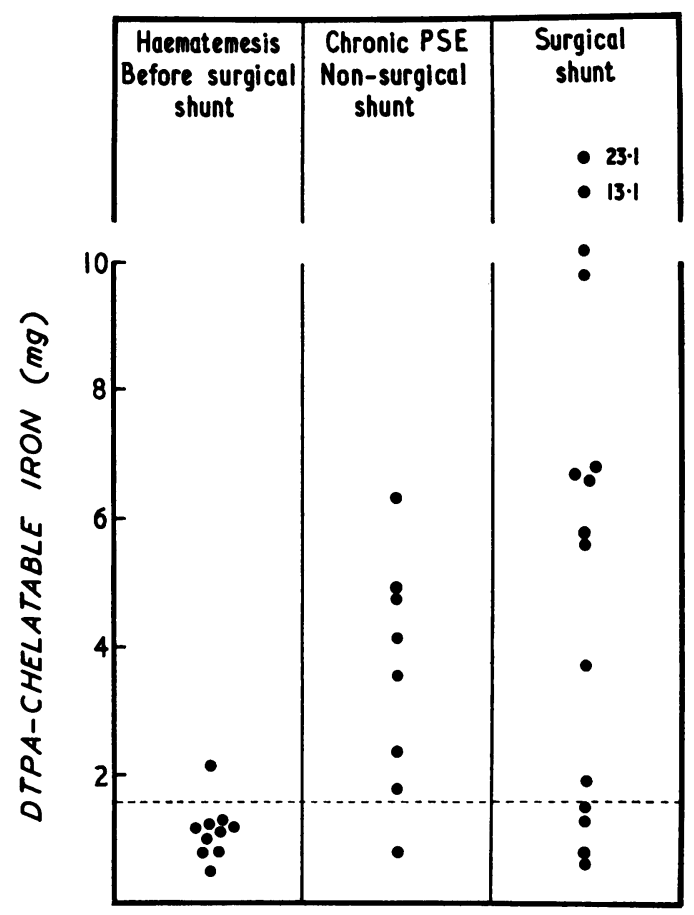

Fig. 4 Comparison of DTPA-chelatable iron in putients with a portacaval anastomosis, patients with recent haematemesis awaiting shunt surgery, and patients with chronic encephalopathy (PSE) due to spontaneous collaterals.

function in chronic alcoholism and in other forms of cirrhosis (Schnack and Wewalka, 1964; Barry, Cartei, and Sherlock, 1969; Lundvall and Weinfeld, 1969), and in our experience does not provide a reliable index of body storage iron in patients with chronic liver disease. However, the same limitation need not necessarily apply to DTPA, which differs from desferrioxamine on both chemical and pharmacological grounds. Studies in patients with iron excess indicated that DTPA-chelatable iron specifically reflects the mobilizable iron stores (Barry et al, 1970); similar studies in the same patients with desferrioxamine showed that this compound derived significant amounts of iron from non-storage sources. Analysis of the present results in subjects with chronic liver disease revealed no tendency for the effect of DTPA to vary with hepatocellular function per se, the normal findings in patients with chronic cholestasis, in particular, contrasting sharply with the greatly increased effect of desferrioxamine in this group (Barry et al, 1969). Furthermore, in as yet unpublished studies we have found a very close correlation between DTPA-chelatable iron and total liver iron concentration in patients with various forms of cirrhosis as well as in those with idiopathic and secondary haemochromatosis. We therefore feel justified in treating the present chelation results as if they solely reflected body storage iron, predicting the latter by means of the previously defined relationship (Barry et al, 1970): iron stores $(\mathrm{g})=0.46 \times$ DTPA-chelatable iron $(\mathrm{mg})$.

Thirty-four out of a total of 69 cirrhotics had chelation values within the control range, corresponding to a total body storage iron content of less than $750 \mathrm{mg}$. The values in another 11 were elevated but indicative of an iron store of less than $1.5 \mathrm{~g}$. Twenty-four cirrhotics had a predicted iron load exceeding $1.5 \mathrm{~g} ; 10$ of these had a portacaval anastomosis, nine had alcoholic cirrhosis, and four (including one of the alcoholics) had chronic encephalopathy due to large portal systemic collaterals; one patient with cryptogenic cirrhosis, who did not fall into any of the above categories, had an iron load of $3 \mathrm{~g}$ for which no cause was apparent.

Although it is widely believed that iron excess and chronic alcoholism are frequently associated, recent quantitative studies of liver storage iron in alcoholics without cirrhosis have given conflicting results, high values being found in Queensland (Powell, 1966) and normal values in Sweden (Lundvall, Weinfeld, and Lundin, 1969). In the present study iron chelation was increased in 14 out of 26 alcoholics with cirrhosis. Obvious exogenous factors for iron excess, in the form of heavy wine consumption or multiple blood transfusions for a haemolytic anaemia, were present in the three patients with the highest values. The remaining cases were all beer and spirit drinkers and in only one of these, whose iron load was confirmed by subsequent venesection, were the predicted stores greater than $2 \cdot 8 \mathrm{~g}$. These findings therefore support the view that alcoholic cirrhosis is potentially an iron-loading state but suggest that in the absence of excessive iron intake, as in wine drinkers, the degree of accumulation falls far short of that found in propositi with idiopathic haemochromatosis. In view of the low iron content of popular British beers and spirits (Table IV) it is necessary to postulate increased absorption from an essentially normal dietary iron intake to account for the moderate iron excess in our patients. This might result from the known ability of alcohol to increase iron absorption (Charlton, Jacobs, Seftel, and Bothwell, 1964) or perhaps be secondarily related to hepatic or pancreatic injury.

\begin{tabular}{lll}
\hline $\begin{array}{l}\text { Beverage }(\text { No. of } \\
\text { brands testeul) }\end{array}$ & \multicolumn{2}{c}{ Iron Concentration $(m g / l)^{1}$} \\
\cline { 2 - 3 } & Mean \pm SEM & Range \\
\hline Red wine (5) & $12.25 \pm 1 \cdot 21$ & $8 \cdot 35-16.83$ \\
White wine (4) & $7.50 \pm 1.41$ & $3 \cdot 17-11.08$ \\
Sherry and port (4) & $4.65 \pm 0.88$ & $2 \cdot 82-7 \cdot 32$ \\
Cider (1) & 2.64 & \\
Stout (1) & 0.81 & \\
Beer (4) & $0.27 \pm 0.04$ & $0.22-0.37$ \\
Whisky (1) & 0.15 & \\
Gin (1) & 0.06 & \\
\hline
\end{tabular}

Table IV Iron content of some alcoholic beverages available in London

${ }^{1}$ Determined by wet ashing. 
The association between increased iron chelation and the presence of large portal systemic collaterals applied both to patients with surgical shunts and to cirrhotics with spontaneous collaterals of sufficient size to cause chronic encephalopathy. Comparison of these with other cirrhotic groups suggested that the effect was related to the presence of the shunt rather than to any concomitant deterioration in liver function, and the higher serum iron and lower values of total iron-binding capacity as well as the greater incidence of hepatic siderosis were further indications of iron excess in these patients. Experimental studies in dogs and rats have also suggested that hepatic siderosis results from the presence of the shunt per se, and that it may develop in the absence of cirrhosis or detectable abnormality on light microscopy (Doberneck, Nunn, Johnson, and Chun, 1963; Rubin, Kohan, Tomita, and Jacobson, 1964); both the type and the size of the shunt appear to be important in these animals. The development of a haemochromatosis-like syndrome in man has been reported after end-to-side portacaval anastomosis (Tuttle et al, 1959; Hoffbauer, 1960; Grace and Balint, 1966), splenorenal anastomosis (Tisdale, 1961; Schaefer et al, 1962), and in association with spontaneous collaterals (Nixon, 1966). The present results suggest that the occurrence of iron excess in such patients may not be as rare as has been believed although in but one case (the only alcoholic) was iron chelation in the range observed in propositi with untreated idiopathic haemochromatosis. Grace and Balint (1966) have also noted that the tissue iron levels in a patient with post-shunt siderosis were far less than in idiopathic haemochromatosis, although the distinction was not possible on pathological grounds. The pathogenesis of iron excess after portacaval anastomosis remains obscure; in our patients the administration of iron or blood did not emerge as a likely factor, and the chelation values showed no correlation with the time since operation. Serial iron absorption measurements combined with quantitative determination of tissue iron stores may resolve this problem.

There was a general correlation between iron chelation and stainable liver iron content. Although the correlation was better in haemochromatosis than in other forms of cirrhosis, in both groups the range of chelation values for each histochemical grade was wide and the overlap between different grades considerable. A similar relationship has been found between non-haem liver iron concentration and stainable liver iron (Morgan and Walters, 1963; Weinfeld, Lundin, and Lundvall, 1968; Lundvall et al, 1969) and it is apparent that iron stores may be normal despite the finding of considerable siderosis.
We are grateful to Dr P. J. Scheuer for the liver biopsy reports and to the Department of Chemical Pathology for performing the liver function tests. DTPA was supplied by Dr J. G. Domenet of Geigy Pharmaceutical Division, Macclesfield. M.B. was in receipt of a Saltwell scholarship of the Royal College of Physicians. The material contained in this paper was included in a thesis submitted by M.B. for the degree of MD at the University of Cambridge.

References

André, J. (1961). Le démembrements des hémochromatoses. Rev. int. Hépat., 11, 113-174.

Barry, M., Cartei, G. C., and Sherlock, S. (1969).। Differential ferrioxamine test in haemochromatosis and liver disease. Gut, 10, 697-704.

Barry, M., Cartei, G., and Sherlock, S. (1970). Quantitative measurement of iron stores with diethylenetriamine penta-acetic acid (DTPA). Gut, 11, 891-898.

Charlton, R. W., Jacobs, P., Seftel, H., and Bothwell, T. H. (1964). Effect of alcohol on iron absorption. Brit. med. J., 2, 1427-1429.

Doberneck, R. C., Nunn, D. B., Johnson, D. G., and Chun, B. K. (1963). Iron metabolism after portacaval shunt in dogs. Arch. Surg., 87, 751-756.

Gilbert, A., and Grenet, A. (1896). Cirrhose alcoolique hypertrophique pigmentaire. C.R. Soc. Biol. (Paris), 3, 10781081.

Grace, N. D., and Balint, J. A. (1966). Hemochromatosis associated with end-to-side portacaval anastomosis. Amer. J. dig. Dis., 11, 351-358.

Kent, G., and Popper, H. (1968). Liver biopsy in diagnosis of hemochromatosis. Amer. J. Med., 44, 837-841.

Hoffbauer, F. W. (1960). Primary biliary cirrhosis: observations on the natural course of the disease in 25 women. Amer. J. dig. Dis., 5, 348-383.

Lundvall, O., and Weinfeld, A. (1969). Iron stores in alcohol abusers. II. As measured with the desferrioxamine test. Acta med. scand., 185, 271-277.

Lundvall, O., Weinfeld, A., and Lundin, P. (1969). Iron stores in alcohol abusers. I. Liver iron. Acta med. scand., 185, 259-269.

MacDonald, R. A. (1964). Hemochromatosis and Hemosiderosis. Thomas, Springfield, Ill.

Morgan, E. H., and Walters, M. N. I. (1963). Iron storage in human disease. J. clin. Path., 16, 101-107.

Nixon, D. D. (1966). Spontaneous shunt siderosis. Amer. J. dig. Dis., 11, 359-366.

Perman, G. (1967). Hemochromatosis and red wine. Acta med. scand., 182, 281-284.

Powell, L. W. (1966). Normal human iron storage and its relation to ethanol consumption. Aust. Ann. Med., 15, 110-115.

Rubin, E., Kohan, P., Tomita, F., and Jacobson, J. H. II (1964) Experimental hepatic siderosis following portacaval shunt. Proc. Soc. exp. Biol. (N.Y.), 115, 350-352.

Schaefer, J. W., Amick, C. J., Oikawa, Y., and Schiff, L. (1962). The development of hemochromatosis following portacaval anastomosis. Gastroenterology, 42, 181-188.

Schnack, H., and Wewalka, F. (1964). Chronic liver disease and iron storage in the liver. T. Gastro-ent., 7b, 342-346.

Tisdale, W. A. (1961). Parenchymal siderosis in patients with cirrhosis after portasystemic shunt surgery. New Engl. J. Med., 265, 928-932.

Tuttle, S. G., Figueroa, W. G., and Grossman, M. I. (1959). Development of hemochromatosis in a patient with Laennec's cirrhosis. Amer. J. Med., 26, 655-658.

Weinfeld, A., Lundin, P., and Lundvall, O. (1968). Significance for the diagnosis of iron overload of histochemical and chemical iron in the liver of control subjects. J. clin. Path., 21, 35-40.

Williams, R., Williams, H. S., Scheuer, P. J., Pitcher, C. S., Loiseau, E., and Sherlock, S. (1966). Iron absorption and siderosis in chronic liver disease. Quart. J. Med., 36, 151-166.

Zimmerman, H. J., Chomet, B., Kulesh, M. H., and McWhorter, C. A. (1967). Hepatic hemosiderin deposits: incidence in 558 biopsies from patients with and without intrinsic hepatic disease. Arch. intern. Med., 107, 494-503. 